\title{
The Effect of chlorine on giardia cyst destruction isolated from different water sources in Maysan province
}

\author{
Rasha Khalil Abudaljalil Alsaad* \\ Lecturer, M Sc Parasitology, College of Pharmacy \& College of Medicine, Maysan University, Maysan, Iraq \\ *Corresponding author E-mail:masterr78@ymail.com
}

\begin{abstract}
G. lamblia was a binucleate flagellated protozoan parasite that infected the upper intestinal tract of human and many animal species. Giardiasis was the most frequently diagnosed water borne disease and the major public health concern of water utilities in the developed and developing nations. Water is an important vehicle for the transmission of Giardia to human and mammals. For identified the effect of chlorine on Giardia cyst. To detect viability of cyst in different chlorine concentration. To determine the threshold level of chlorine concentration that caused cyst destruction. Measure the $\mathrm{pH}$, chlorine concentration, filtration processes and examined by zinc sulfate centrifugal flotation technique using. 50\% of samples contain Giardia cysts which are untreated water sources. Cyst viability differs in different chlorine concentration in different period of time extend from few hours to more than twenty days. The extreme chlorine concentration which caused cyst destruction in hours is $1.5 \mathrm{mg} / \mathrm{L}$.
\end{abstract}

Keywords: Giardia; Waterborne; Chlorination; Filtration; Chloro-Meter; Reverse Osmosis.

\section{Introduction}

The genus Giardia falls within the phylum Sarcomastigophora, class Zoomastigophora, order Diplomonadida and family Hexamitidae. It includes six valid species that inhabit the intestinal tracts of virtually all classes of vertebrates, with $\mathrm{G}$. duodenalis being the only species found in humans [1], [2]. Giardia has been known since the seventeenth-century work by Antony van Leeuwenhoek, although for most of this time, this protozoa has been considered a harmless intestinal commensal, primarily because the parasite was identified in asymptomatic individuals. It was not until 1987 that the pathogenic nature of Giardia was definitively confirmed in a study of infection in human volunteers [3]. Giardia lamblia (syn. G. duodenalis, G. intestinalis) is an intestinal flagellate that infects a wide range of vertebrate hosts, such as domestic and wild mammals, including humans. Theses flagellates have a simple two stages life cycle consisting of the reproductive trophozoite stage and the environmentally robust cyst stage [4]. Cysts are shed by infected hosts into the environment and these cysts can survive in the environment for months without losing their infectivity. Transmission of Giardia is common in certain high-risk groups. Children, workers in day-care centers and / or sewage / irrigation processes, those who are exposed to contaminated water and /or certain animals, travelers and the immunocompromised, are known to be more susceptible to infection [5]. Water is responsible for a quarter of endemic Giardia infections in the USA and the role of contaminated municipal water supplies in epidemic outbreaks of giardiasis is undeniable. This protozoan parasite has been recognized as a frequent cause of waterborne disease $[6,7,8$, and 9] because of their strong resistance against chlorine disinfection [10] as well as the low minimum infectious dose [11]. Many of the waterborne outbreaks in 1980s have been associated with the ingestion of untreated surface water by hikers and campers in the USA, Canada, England, Sweden, but giardiasis outbreaks have not been limited only to these people. Some waterborne outbreaks were reported in some municipal drinking water systems, and then the United States Environmental Protection Agency (USEPA) has regulated treatment techniques for a sufficient removal of Giardia cysts at water treatment plants as one of the drinking water rules [10]. Microbial contamination of groundwater is a serious concern worldwide. For many countries, groundwater provides approximately $40 \%$ of the potable water used for human consumption [9], [12]. Cyst-forming protozoans such as Giardia intestinalis and Cryptosporidium parvum, viruses such as Hepatitis A, and even pathogenic bacteria such as certain E. coli strains can survive for extended periods of time in ground water systems with temperatures of less than $10^{\circ} \mathrm{C}$, migrate significant distances, and are relatively resistant to standard municipal water system chlorination practices. Though dormant outside the host, as few as ten cysts can result in a human infection [12]. Giardia is more frequently found in surface waters than Cryptosporidium, and it has been associated with at least 132 waterborne outbreaks worldwide [13]. However, giardiasis outbreaks have not been limited only to people who ingest untreated surface water, since in many municipalities using only chlorine for disinfection, outbreaks of giardiasis have been reported after the consumption of the treated water [14]. The environmental study showed that water, whether drinking water, washing and sewage come in the first place and basic of disease transmission between human and animals and vice versa compared to other modes of transmission [15]. Though dormant outside the host, as few as ten cysts can result in animal or human infection, [16], and [17]. G. intestinalis is the most frequently identified protozoan agent causing waterborne outbreaks of parasitic infections in humans in the world [18], [19]. 


\section{Methods \& materials}

In this work, 10 liters were collected in sterile glass bottles tightly closed from each source of different sources of water (river water, water marshes, water pools, taped water, water purification stations and RO water) in Maysan, Iraq Conducted a measurement process for the $\mathrm{pH}$ proportion and chlorine concentration for each sample of water by using two devices the $\mathrm{pH}$ meter (Hanna/ Romania) and chloro-meter (Accue/ China).

By using a Domestic Reverse Osmosis Unit (Sony Classic/ China) for the purpose of filtering each samples of water on separately ways, the steps are:

1) First stage: removing the particles, dust and mud.

2) Second stage: removing organics, odor and turbidity.

3) Third stage: removing organics and turbidity.

4) Fourth stage: removing bacteria, protozoa cyst, heavy metal, mineral substance and other dissolved matter.

Then changing the filtering tubes for each filtration processes separately and uses a new filtering tubes for each next filtering step to get sediment in each sample and examined by zinc sulfate centrifugal flotation technique by use sediment samples collecting by filtering tubes instead off stool samples according to [20] and then investigate cyst of Giardia by direct smear with normal saline according to [21], [22]. The positive samples were taken and, which contained Giardia cyst.

Each positive sediment gives symbols for differentiation from other as follows:

\begin{tabular}{llllll}
\hline $\begin{array}{l}\text { River } \\
\text { water }\end{array}$ & $\begin{array}{l}\text { Water } \\
\text { marshes }\end{array}$ & $\begin{array}{l}\text { Water } \\
\text { pools }\end{array}$ & $\begin{array}{l}\text { Taped } \\
\text { water }\end{array}$ & $\begin{array}{l}\text { Water purifica- } \\
\text { tion stations }\end{array}$ & $\begin{array}{l}\text { RO } \\
\text { water }\end{array}$ \\
\hline M 1 & M 2 & M 3 & M 4 & M 5 & M 6 \\
\hline
\end{tabular}

Tow grams of positive samples used to put them in different concentrations of chlorine to see the effect of sterilized rule on the cysts and to determine the concentration for Giardia cyst destruction.

\section{Main results}

Each 10 liters of different water source have different chlorine concentration and $\mathrm{pH}$ level in table (1) below.

The microscope examination identified $50 \%$ of samples contain Giardia cysts which are M1, M2 and M3, table (2).

Different chlorine concentration and cyst (viability and activity) among several day work show different results as in table (3).

Table 1: Water Sources and Its Chlorine Concentration and $\mathrm{Ph}$

\begin{tabular}{lll}
\hline Water source & $\mathrm{Cl} 2$ concentration $\mathrm{mg} / \mathrm{L}$ & $\mathrm{pH}$ \\
\hline M 1 & 0 & 10.1 \\
M 2 & 0 & 12.5 \\
M 3 & 0 & 12.7 \\
M 4 & 0.1 & 8.9 \\
M 5 & 0.2 & 8.1 \\
M 6 & 0.6 & 7.2 \\
\hline
\end{tabular}

Table 2: Sediment Samples and Giardia Cysts Present

\begin{tabular}{lc}
\hline Sediment samples & cyst \\
\hline M 1 & + \\
M 2 & + \\
M 3 & + \\
M 4 & - \\
M 5 & - \\
M 6 & -
\end{tabular}

Table 3: Chlorine Concentration and Giardia Cyst Viability

\begin{tabular}{lll}
\hline $\mathrm{Cl} 2$ concentration $\mathrm{mg} / \mathrm{L}$ & Cyst viability & Duration of activity \\
\hline$\leq 0.2$ & + & $\geq 20$ days \\
$0.3-0.4$ & + & $10-15$ days \\
$0.5-0.8$ & + & $7-9$ days \\
$1.0-1.2$ & + & $3-6$ days \\
$1.4-1.5$ & + & $1-2$ days \\
$>1.6$ & & Few hours
\end{tabular}

\section{Discussion}

The results of work showed present of Giardia parasite in different raw water sources as rivers, marshes and pools, so water plays an important rule in transmission of parasite to different hosts, and this agrees with [4], [23], [24], and [25]. This is due to all these water sources are untreated. The $50 \%$ of sediment samples contain Giardia and this similar to [25], [26]. There are several factors contributing to the occurrence of waterborne outbreaks. Cyst concentration in drinking water and parasite host specificity, infectivity, and virulence as well as population susceptibility are complex, interacting variables. Acquired immunity was noted in one study comparing attack rates of residents with those of visitors during a waterborne outbreak of giardiasis [27]. Another recent community study showed that residents with laboratory- confirmed giardiasis from one waterborne outbreak were much less likely to be infected in the second outbreak [28]. The viability of Giardia cyst is different in different chlorine concentration, cyst remain viable at 0.2 , $0.3,0.4,0.5,0.8,1.0,1.2$ and $1.4 \mathrm{mg} / \mathrm{L}$ for a different period of time, but cyst destruction occur when concentration reach more than $1.5 \mathrm{mg} / \mathrm{L}$. The prevention of $\mathrm{G}$. duodenalis infections is a difficult task since the cysts are ubiquitous, resist environmental decomposition and remain viable for a considerable period of time [29]. The disinfection and cleaning of surfaces should occur utilizing products such as organic iodine, tincture of iodine, chlorine or bleach (hypochlorite) to reduce contact with viable cysts by potential hosts [30]. Systems providing drinking water should use coagulo-sedimentation and filtration as methods of purification in order to prevent waterborne giardiasis outbreak [31]. Chlorination only is effective and kills most enteropathogenic organisms, but Giardia cysts require higher concentrations and more prolonged exposure to chlorine to be killed, especially in cold-water [17].

\section{Conclusion}

Water is present as important vector for transmission Giardia. Disinfection processes of water not enough method for treated drinking water. Combination of chlorination, filtration and disinfection of water is more effective in treated water and in killing all parasites, including Giardia.

\section{References}

[1] Monis PT, Caccio SM, Thompson RC. Variation in Giardia: towards a taxonomic revision of the genus. Trends in Parasitology. 2009; 25:93-100. http://dx.doi.org/10.1016/j.pt.2008.11.006

[2] Caccio SM, Ryan U. Molecular epidemiology of giardiasis. Molecular and Biochemical Parasitology. 2008; 160:75-80 http://dx.doi.org/10.1016/j.molbiopara.2008.04.006.

[3] Nash TE, Herrington DA, Losonsky GA, Levine MM. Experimental human infections with Giardia lamblia. Journal of Infectious Diseases. 1987; 156:974-984. http://dx.doi.org/10.1093/infdis/156.6.974.

[4] deRegnier DP, Cole L, Schupp DG, Erlandsen SL. Viability of Giardia cysts suspended in lake, river, and tap water. Appl. Environ. Microbiol. 1989; 55: 1223-1229.

[5] Hoque ME, Hope VT, Kjellstrom T, Scragg R and Lay-Yee R. Risk of giardiasis in Aucklanders a case-control studies. Inter. J of Infec Disea. 2002; 6: 191.

[6] Okell RS and Wright JM. Giardia lamblia - An assessment from the Eastern Bay of Plenty: September 1986 - September 1989. NZ J Med Lab Technol. 1990; 44(3): 64-66.

[7] Dykes AC, Juranek DD, Lorenz RA, Sinclair S, Jakubowski W, Davies R. Municipal waterborne giardiasis: An epidemiologic investigation. Ann Inter Med 1980; 92: 165-170. http://dx.doi.org/10.7326/0003-4819-92-2-165.

[8] Craun GF. Waterborne outbreaks of giardiasis, current status. In: Erlandsen SL and Meyer EA (Eds). Giardia and Giardiasis: Biology, Pathogenesis, and Epidemiology. New York, USA. Plenum Publishing Corp. 1984; p: 243-261. http://dx.doi.org/10.1007/978-14899-0594-9 15 
[9] Herwalt BL, Kramer HM, Craun GF, Calderon RL and Juranek DD. Waterborne diseases: 1993 and 1994. J Am Water Works Assoc. 1996; 88: 66-79.

[10] United States Environmental Protection Agency (USEPA). National Primary Drinking Water Regulations; Surface Water Treatment Rule. 1989; 141.70-141.80.

[11] Schaefer FW, Johnson CH, Hsu CH and Rice EW. Determination of Giardia lamblia cyst infective dose for the Mongolian gerbil (Meriones unguiculatus). Appl Environ Microbiol. 1991; 57: 24082409.

[12] Casemore DP, Wright SE and Coop RL. In: Fayer R (Ed). Cryptosporidium and Cryptosporidiosis. CRC Press, Boca Raton, FL. 1997; p: 65-92.

[13] Karanis P, Kourenti C and Smith H. Waterborne transmission of protozoan parasites: a worldwide review of outbreaks and lessons learnt. Journal of Water and Health. 2007; 5: 1-38. http://dx.doi.org/10.2166/wh.2006.002.

[14] Kent GP, Greenspan JR, Herndon JL, Mofenson LM, Harris JS Eng TR, and Waskin HA. Epidemic giardiasis caused by a contaminated public water supply. Am J Publ Health. 1988; 78(2):139-143. http://dx.doi.org/10.2105/AJPH.78.2.139.

[15] Al-Saad RKA. Biological and molecular study of Giardia parasite as a zoonotic potential in human and animal at northern Basrah, Iraq. M.Sc. Thesis. Veterinary Medicine Collage, University of Basrah. 2014; P: 141.

[16] Akin EW and Jakubowski W. Drinking water transmission of giardiasis in the United States. Water Sci Technol. 1986; 18:219-226.

[17] Jarroll EL, Bingham AK and Meyer EA. Effect of chlorine on Giardia lamblia cyst viability. Appl Environ Microbiol. 1981; 41: 483-487.

[18] Isaac-Renton J, Cordeiro C, Sarafis K and Shahriari H. Characterization of $\mathrm{G}$. duodenalis isolates from a waterborne outbreak. $\mathrm{J}$ of Infec Disea. 1993; 62: 2789-2797.

[19] Environmental Protection Agency US (EPA). Final Long Term 2 Enhanced Surface Water Treatment Rule. Office of Water (4606-M) EPA 815-R-06-002 December 2005. ww.epa.gov/safe water.

[20] Chatterjee KD. Parasitology, protozoology and helminthology, 13th Ed. New Delhi, India. Thomson Press (India) Ltd. 2009; p: 263.

[21] Markell EK, Jone DT and Krotoski WA. Markell and Voges Medical Parasitology. 8th ed. W.B. Saunders co. Philadelphia. 1999; p: 55-445.

[22] Al-Emarah GYA, AL-Ali SJK and AL-Idresi SRA. Atlas of Parasites. 1st ed. Al-Salam printing, Basrah, Iraq. 2009; Part1, p: 7-10.

[23] Gillespie SH and Pearson RD. Principles and Practice of Clinical Parasitology. 1st ed. John W. and Sons Ltd., England. 2001; p: 219 241. http://dx.doi.org/10.1002/0470842504.

[24] Marshall MM, Naumovitz D, Ortega Y and Sterling CR. Waterborne protozoan pathogens. Clin Microbiol. 1997; 0: 69-76.

[25] LeChevallier M, Norton W and Lee R. Occurrence of Giardia and Cryptosporidium spp. In surface water supplies. Appl Environ Microbiol. 1991; 57: 2610-2616.

[26] LeChevallier MW and Norton WD. Impact of the enhanced surface water treatment rule on water utility operations. In: Proceedings of the 1993 American Water Works Association Water Technology Quality Conference, Miami, Fla. American Water Works Association, Seattle. 1993; p: 1733-1737.

[27] Istre GR, Dunlop TS, Gaspard GB, and Hopkins RS. Waterborne giardiasis at a mountain resort: evidence for acquired immunity. Am J Public Health. 1984; 74:602-604. http://dx.doi.org/10.2105/AJPH.74.6.602.

[28] Isaac-Renton J, Lewis L, Ong CSL and Nulsen MF. A second community outbreak of waterborne giardiasis in Canada and serological investigation of patients. Trans R Soc Trop Med Hyg. 1994; 88:33-35. http://dx.doi.org/10.1016/0035-9203(94)90397-2.

[29] Olson ME and Buret AG. Giardia and Giardiasis. In: Samuel WM, Pybus MJ and Kocan AA (Eds.). Parasitic Diseases of Wild Animals.1st ed. Iowa State University Press. USA. 2001; Pp: 399-416. http://dx.doi.org/10.1002/9780470377000.ch16b.

[30] Olson ME, Goh J, Phillips M, Guselle N and McAllister TA. Giardia cyst and Cryptosporidium oocyst survival in water, soil and cattle feces. J Environ Quality. 2000; 28: 1991-1996. http://dx.doi.org/10.2134/jeq1999.00472425002800060040x.

[31] Ivanov AI. Giardia and giardiasis. Bulg J Vet Med. 2010; 13(2): 65-80. 